DISTRIBUTION SHEET

\begin{tabular}{|c|c|c|c|c|c|}
\hline \multirow{2}{*}{$\begin{array}{l}\text { To } \\
\text { LLW Vitrification Program }\end{array}$} & \multirow{2}{*}{\multicolumn{3}{|c|}{$\begin{array}{l}\text { From } \\
\text { STS/ETT/Engineered Process } \\
\text { Applications }\end{array}$}} & \multicolumn{2}{|l|}{ Page 1 of 1} \\
\hline & & & & \multicolumn{2}{|c|}{ Date $05 / 15 / 95$} \\
\hline \multicolumn{4}{|l|}{ Project Title/Work Order } & \multicolumn{2}{|c|}{$\begin{array}{l}\text { EDT No. } 611404 \\
\text { [WHC-SD-WM-ER-434, } \\
\text { Rev. 0] }\end{array}$} \\
\hline \multicolumn{4}{|c|}{$\begin{array}{l}\text { LLW Vitrification Technology Development/PTasma Arc } \\
\text { Vitrification (PO MMI-SWV-384212 WSTC) }\end{array}$} & \multicolumn{2}{|c|}{ ECN No. } \\
\hline Name & MSIN & $\begin{array}{l}\text { Text } \\
\text { With All } \\
\text { Attach. }\end{array}$ & Text Only & $\begin{array}{l}\text { Attach./ } \\
\text { Appendix } \\
\text { Only }\end{array}$ & $\begin{array}{l}\text { EDT/ECN } \\
\text { Only }\end{array}$ \\
\hline
\end{tabular}

Central Files (Orig. + 2)

L8-04 X

M. J. Bowman

G1-62

P. J. Brackenbury

$\mathrm{HO}-33$

K. C. Burgard

G6-13

D. W. Duncan

G6-07

R. L. Gibby

D. W. Hendrickson (2)

H5-27

L5-31

B. A. Higley

H5-27

J. A. Hunter

L. A. Palmer (3)

[5-3]

H5-27

E. S. Mast

L4-69

D. E. Mitchell

H5- 49

R. H. Rieck

J. W. Shade

E. R. Siciliano

G6-06

H5-27

HO-31

C. N. Wilson

H5-27

$x$

$\mathrm{X}$

$x$

$x$

$x$

$x$

$x$

$x$

$\underset{x}{x}$

$X$

$x$

$x$

Pacific Northwest Laboratory
C. J. Freeman
P7-41
G. A. Whyatt
P7-19
$\mathrm{X}$
$\mathrm{X}$

U. S. Department of Energy - Richland Operations
C. V. Banks
N. R. Brown
S. T. Burnum
L. A. Huffman
G. H. Sanders

S7-53

$57-53$

$57-53$

S7-53

S7-53

$x$
$x$
$x$
$x$
$x$

OSTI (2)

L8-07

$x$ 


\section{DISCLAIMER}

Portions of this document may be illegible in electronic image products. Images are produced from the best available original document. 


2. To: (Receiving organization)
TWRS Vitrification
Development

5. Proj./Prog./Dept./Div.:

TWRS LLW Program

8. Originator Remarks:

Westinghouse Science and Technology Center (WSTC) Plasma Arc Vitrification, Technical Summation document for approval and release.

11. Receiver Remarks:

\section{From: (Originating organization) STS/ETT/Engineered Process Applications}

\section{Cog. Engr.:}

D. W. Hendrickson
4. Related EDT No.:

611401

7. Purchase Order No.:

MMI-SVV-384212 WSTC

9. Equip./Component No.:

$\mathrm{N} / \mathrm{A}$

10. System/Bldg./Facility:

N/A

12. Major Assm. Dwg. No.

$N / A$

13. Permit/Permit Application No.: N/A

14. Required Response Date:

May 15, 1995

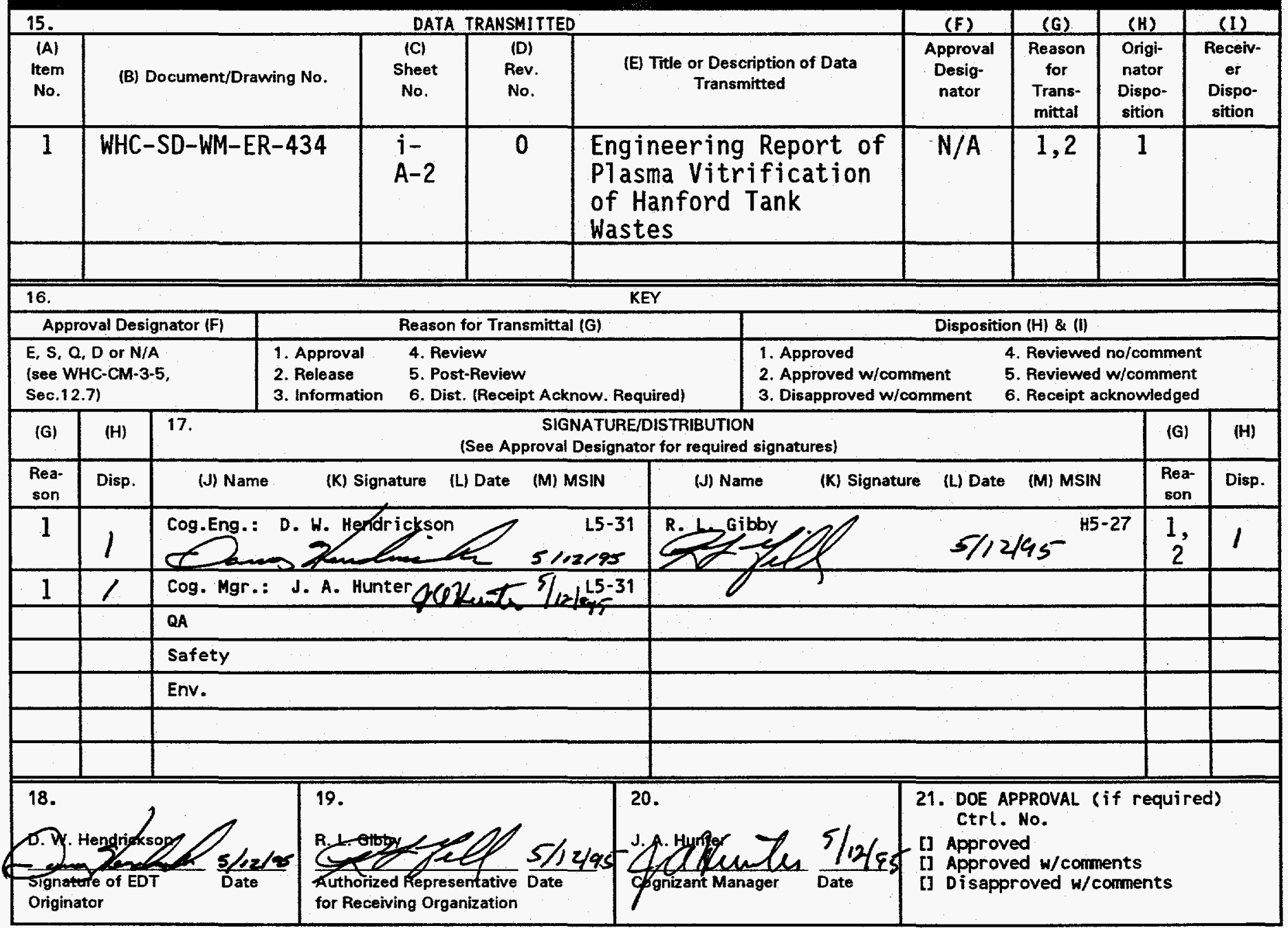

BD-7400-172-2 (04/94) GEF097 


\section{RELEASE AUTHORIZATION}

Document Number: WHC-SD-WM-ER-434, Rev. 0

Document Title: $\quad$ ENGINEERING REPORT OF PLASMA VITRIFICATION OF

HANFORD TANK WASTES

Release Date: $\quad 5 / 12 / 95$

This document was reviewed following the procedures described in WHC-CM-3-4 and is:

\section{APPROVED FOR PUBLIC RELEASE}

WHC Information Release Administration Specialist:

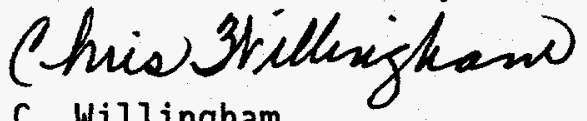

c. Willingham

TRADEMARK DISCLAIMER. Reference herein to any specific comnercial product, process, or service by trade name, trademark, manufacturer, or otherwise, does not necessarily constitute or imply its endorsement, recommendation, or favoring by the United States Government or any agency thereof or its contractors or subcontractors.

This report has been reproduced from the best available copy. Available in paper copy and microfiche. Printed in the United States of America. Available to the U.s. Department of Energy and its contractors from:

U.S. Department of Energy Office of Scientific and Technical Information (OSTI)

P.0. Box 62

Dak Ridge, TN 37831

Telephone: (615) 576-8401

Available to the public from:

U.S. Department of Commerce

National Technical Information Service (NTIS)

5285 Port Royal Road

Springfield, VA 22161

Telephone: (703) 487-4650 


\begin{tabular}{l|l|c|}
\hline 2. Title & $\begin{array}{l}\text { 3. Number } \\
\text { WHC-SD-WM-ER-434 }\end{array}$ & $\begin{array}{c}4 . \text { Rev No. } \\
\text { Engineering Report of Plasma Vitrification of } \\
\text { Hanford Tank Wastes }\end{array}$ \\
\hline $\begin{array}{l}\text { 5. Key words } \\
\text { Vendor. Radioactive. LLW. Waste. } \\
\text { Vitrification. Glass. Melter. Testing. Hanford. } \\
\text { Sodium. Operability. Maintenance. Reliability. }\end{array}$ & $\begin{array}{l}\text { 6. Author } \\
\text { Organization/Charge Code OM570/D42AN }\end{array}$ \\
\hline
\end{tabular}

7. Abstract

This document provides an analysis of vendor-derived testing and technology applicability to full scale glass production from Hanford tank wastes using plasma vitrification. The subject vendor testing and concept was applied in support of the Hanford LLW Vitrification Program, Tank Waste Remediation System.

\section{DISCLAIMER}

This report was prepared as an account of work sponsored by an agency of the United States Government. Neither the United States Government nor any agency thereof, nor any of their employees, makes any warranty, express or implied, or assumes any legal liability or responsibility for the accuracy, completeness, or usefulness of any information, apparatus, product, or process disclosed, or represents that its use would not infringe privately owned rights. Reference herein to any specific commercial product; process, or service by trade name, trademark, manufacturer, or otherwise does not necessarily constitute or imply its endorsement, recommendation, or favoring by the United States Government or any agency thereof. The views and opinions of authors expressed herein do not necessarily state or reflect those of the United States Government or any agency thereof.
8. RELEASE STAMP

OFFICIAL RELEASE

BYyir

DATE MAY 121995

35 
WHC-SD-WM-ER-434, Revision 0

THIS PAGE INTENTIONALLY LEFT BLANK 
WHC-SD-WM-ER-434, Revision 0

\title{
Engineering Report of the Plasma Vitrification of \\ Hanford Tank Wastes
}

\author{
Prepared for \\ Westinghouse Hanford Company \\ D. W. Hendrickson \\ Westinghouse Hanford Company \\ May 1995
}


WHC-SD-WM-ER-434, Revision 0

THIS PAGE INTENTIONALLY LEFT BLANK 
WHC-SD-WM-ER-434, Revision 0

TABLE OF CONTENTS

PAGE

1.0 OBJECTIVE $\ldots \ldots \ldots \ldots \ldots \ldots \ldots \ldots$

1.1 BACKGROUND AND SCOPE .................. . . . . . .

1.1.1 Background ................... 1-1

1.1 .2 Scope ................... . . 1-1

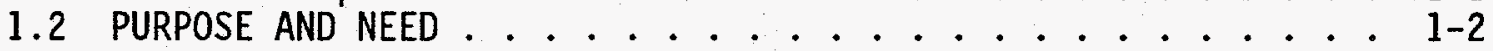

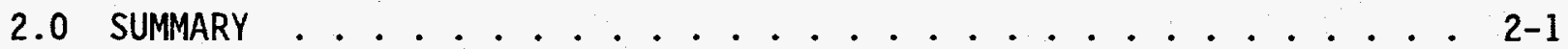

3.0 RECOMMENDATIONS AND CONCLUSIONS ............. $3-1$

3.1 RECOMMENDATIONS ..................... . . . . . . . . . . . . .

3.2 CONCLUSIONS ........................

4.0 UNCERTAINTIES . . . . . . . . . . . . . . . . 4-1

4.1 CORROSION ................. . . . . .

4.2 MATERIAL LOSSES AND VOLATILITIES . . . . . . . . 4-1

4.3 GLASS FORMULATION ................. . . . . . .

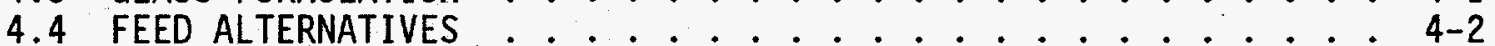

4.5 MAINTENANCE AND OPERABILITY .............. . . . . 4-4

4.6 FEED HANDLING AND MIXING . . . . . . . . . . . . . 4-4

5.0 DESCRIPTION OF THE TECHNOLOGY AND ITS APPLICATION . . . . . . 5-1

5.1 DESCRIPTION OF PLASMA VITRIFICATION .......... . . 5-1

5.2 PHASE I TEST CONDUCT AND RESULTS ........... $5-1$

5.2 .1 First Scoping Test . . . . . . . . . . 5-2

5.2 .2 Second Scoping Test .............. 5-5

5.2 .3 Third Scoping Test . . . . . . . . . . . . . 5-7

5.2 .4 Demonstration Test . . . . . . . . . . 5-9

5.3 PRODUCT QUALITY AND PRODUCTION RATE .......... . 5-16

5.3 .1 Product Quality ............. 5-16

5.3.2 Production Rate ............. . 5-17

5.4 FULL SCALE APPLICATION ............. . . 5-18

5.4.1 Facility Description ........... . . . . . . .

5.4.2 Scale-Up Assessment and Contingencies ..... 5-19

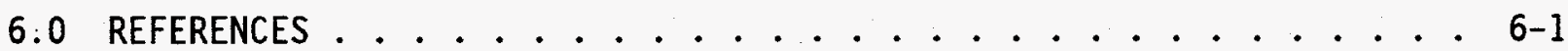

APPENDIX A - PHOTOGRAPHIC RECORDS ............... . . . 
WHC-SD-WM-ER-434, Revision 0

\section{LIST OF FIGURES}

PAGE

Figure 1: Westinghouse Science and Technology Plasma Vitrification Melter . . . . . . . . . . . . . 5-2 Figure 2: Barium Tracer Evaluation of Residence time . . . . . . 5-6 Figure 3: WSTC Plasma Vitrification Melter Configuration. . . . . 5-7 Figure 4: Temperature Profiles upon Plasma Torch Vitrification Initiation ................... 5-8

Figure 5: Third Scoping Test G7ass Composition ......... . 5-9

Figure 6: WSTC Plasma Melter and Offgas System Configuration . . . . 5-11

Figure 7: WSTC Offgas Train Piping Arrangement ......... 5-12

Figure 8: WSTC Demonstration Test Glass Analyses . . . . . . . 5-16

Figure 9: Plasma Melter Core Operations ........... . 5-18

\section{LIST OF TABLES}

Table 5: Product Glass Retention of Waste and Frit Constituents ... PAGE

Table 6: Phase I Glass Formulation .............. 4-3

Table 7: Third Scoping Test Glass Analyses (wt\%) . . . . . . . . 5-10

Table 8: Demonstration Test Glass Analyses (Wt\%) ........ . 5-17

Table 9: Demonstration Test Glass PCT Leach Analyses ...... . . 5-16

Table 10: Plasma Melter Core Operations Stream Definitions . . . . . . 5-19 
WHC-SD-WM-ER-434, Revision 0

\section{Engineering Report of the Plasma Vitrification of Hanford Tank Wastes}

\subsection{OBJECTIVE}

The objective of this engineering report is to describe the application of plasma vitrification to Hanford tank wastes. Information that must be considered in such a report includes a description of the technology, physical test configurations and results, conceptual application to the mission, scale assessment, development requirements, and advantages and disadvantages of the technology.

\subsection{BACKGROUND AND SCOPE}

This section describes the background upon which the work in the demonstration of plasma vitrification was conducted, and the scope of this document in describing the work.

\subsubsection{Background}

Pursuant to treatment objectives for Hanford Site tank wastes, the

Westinghouse Hanford Company (WHC) Low-Level Waste (LLW) Vitrification Program requested proposals for the demonstration of vitrification processes. The Westinghouse Science and Technology Center (WSTC) successfully proposed and was awarded a contract under Purchase Order MMI-SVV-384212.

The basis for the WSTC proposal was the application of their Plasma Fired Vitrification Melter (plasma melter). The unit is fired with a Westinghouse commercial non-transferred arc plasma torch. The torch is mounted onto a shaft furnace originally constructed for metal refining. The physical mounting of the torch to the shaft of the furnace is onto the end of a pipelike segment called a tuyere. The tuyere is refractory lined, water jacketed, and penetrated with the waste feed line. The waste and glass forming materials are thus injected into the plasma plume and proceed through evaporation, calcination, melting, and refining reactions before being collected in the bottom of the furnace and removed from the tap.

WSTC has successfully operated their plasma facilities on Hanford wastes in the calcination of such wastes (Delegard et al. 1994).

\subsubsection{Scope}

The scope of this report is to provide a synopsis of the technology being applied for low-level waste vitrification, test work to date, facility and technology benefits and disadvantages, and to describe the applicability of 
WHC-SD-WM-ER-434, Revision 0

the technology to a full scale melter facility with a production capacity of 200 MT/day.

Separate analyses, not within the scope of this document, must be conducted for particular Hanford application considerations such as overall flowsheet modeling, hazard and environmental analyses, construction siting, and construction and operating cost analyses.

\subsection{PURPOSE AND NEED}

All of the above information is required in order to fully evaluate the support requirements for such a facility and the efficacy of continued testing toward deployment of this technology. The purpose of this document is to provide an initial basis for election of further facility testing.

1 Instantaneous 200 metric tons per day. 
WHC-SD-WM-ER-434, Revision 0

\subsection{SUMMARY}

The Westinghouse Plasma Melter is the basis for the vitrification process proposed by WSTC for Hanford's low-level waste. The overall process is relatively simple and involves no required pretreatment of the waste other than evaporation to improve efficiency. The WSTC Waltz Mill Plasma Center contains the facility where tests for this program and prior calcination activities occurred.

Phase I testing of the WSTC PIasma Melter for the Hanford LLW Vitrification program was proposed and executed as a series of three scoping tests and one final demonstration test. The testing occurred between October 13, 1994 and December 8,1994 . These tests produced glass product at a mean rate of $6.9 \mathrm{MT} /$ day with an average applied power of $1.55 \mathrm{MWe}$.

The testing undertaken by WSTC during the first phase of activities under the statement of work (Wilson 1994) highiighted and/or resolved uncertainties related to vitrification operations in general and plasma operation in specific. Uncertainties considered herein include corrosion, material losses and volatilities, feed alternatives (batch versus frit), maintenance and operability, feed handling and mixing, and glass formulations. Although not all concerns associated with these uncertainties were resolved during phase I testing, a reasonable path-forward exists for resolution.

The glass produced during testing has met durability and crystallinity constraints proposed in the statement of work (Wilson 1994) with sodium leach rates a minimum of twenty times better than required while retaining sodium oxide in the glass at concentrations exceeding $20 \%$.

Concerns of full scale application of this technology are eased upon noting that the scale-up factor proposed by the vendor is approximately 0.75 to 1.0 . The modularity of the plasma melter concept reasonably allows the vendor to propose the application of a facility containing three to four melters each operating ten torches of the same throughput as the test unit. The torch used during testing is a current commercial product of the Westinghouse Electric Company. 
WHC-SD-WM-ER-434, Revision 0

THIS PAGE INTENTIONALLY LEFT BLANK 
WHC-SD-WM-ER-434, Revision 0

\subsection{RECOMMENDATIONS AND CONCLUSIONS}

\subsection{RECOMMENDATIONS}

It is the recommendation of this author that further consideration of deployment of this technology be taken. In doing so, it is recommended that specific tests be conducted evaluating: 1) the need of, or selection of, tuyere refractory; 2) reduction or elimination of shroud gas to a tuyere; 3) detailed volatilization/retention data for materials with low glass solubility and high volatility at these conditions; 4) batchformer versus frit feed operation for non-boron containing glasses; and, 5) potential contaminant mitigation through $\mathrm{NO}_{\mathrm{x}}$ treatment within either the plume or the offgasses.

\subsection{CONCLUSIONS}

Conclusions from the conduct of work performed by WSTC under the statement of work (Wilson 1994) include:

- The vendor successfully melted a high-sodium borosilicate glass in a series of tests under an aggressive schedule.

- The vendor glass exceeded durability and crystallinity requirements of the contract.

- Volatilization concerns existed for this high-temperature process; testing has indicated significant material retention and the pointed to methods for further retention.

- The vendor has proposed a concept for a full scale facility based upon the modularity of their current commercial plasma torch. This facility would have relatively small hot cell requirements while enabling on-line maintenance and a high total operating efficiency. Modularity, small dimension, small inventory, and the capability to be easily maintained in a radioactive environment are all aspects highly desired in the deployment of LLW vitrification. 
WHC-SD-WM-ER-434, Revision 0

THIS PAGE INTENTIONALLY LEFT BLANK 
WHC-SD-WM-ER-434, Revision 0

\subsection{UNCERTAINTIES}

The testing undertaken by WSTC during the first phase of activities under the statement of work (Wilson 1994) highlighted and/or resolved uncertainties related to vitrification operations in general and plasma operation in specific.

\subsection{CORROSION}

Melter refractory corrosion is endemic and eternal to consideration of the operability of a melter for the desired application. During phase I testing, WSTC demonstrated the durability of high chromium ('ruby') refractory in the crucible. Due in part to impingement of the plume, WSTC also demonstrated significant corrosion and erosion of corundum-mullite cast refractory in the tuyere. Additional studies of refractory survival, as well as cold-skull operation, in these vitrification conditions should be conducted if deployment of plasma vitrification is further considered.

\subsection{MATERIAL LOSSES AND VOLATILITIES}

Table 5 details preliminary analyses of material retention in the glass product. As some question currently exists with regard to waste simulant analysis, the data is displayed as a ratio of material in the glass product divided by the total analyte found within and having exited the melter. Noticeably, boron losses are approximately $12.5 \%$ and sodium losses approximately $13 \%$ (approximately $4-5 \%$ of sodium as borates). It appears that the boron may be aiding the loss of the sodium from the melt. Additionally, potassium, cesium, molybdenum, fluoride, and chloride exhibited relatively high losses. The majority of these losses are apparently due to volatilization. Some $(0.7 \%)$, as indicated by relative retention of silica and calcium, is lost through entrainment.

Volatilities of these low retention materials should be further evaluated if this technology is to be considered for deployment. Material entrainment, although relatively low in this application, may be further minimized by reducing the gas velocity. The gas velocity may be reduced by reducing gas mass flow rate into the melter or expanding the melter diameter. For purposes of this program, only reduction of the shroud gas mass flow rate would reasonably reduce entrainment.

\subsection{GLASS FORMULATION}

The glass composition selected for testing during the first phase of tests is detailed in Table 6 . This formulation was developed with the support of the Westinghouse Savannah River Technology Center. Because the material was being prepared as a frit, lithia was added for ease of preparation. The bolosilicate glass formulations are anticipated to continue to exhibit strong boron losses as sodium borate compounds. 
WHC-SD-WM-ER-434, Revision 0

Table 5: Product Glass Retention of Waste and Frit Constituents

\begin{tabular}{|c|c|c|c|}
\hline Analyte & $\begin{array}{l}\text { Product-Based } \\
\text { Retention }(\%)\end{array}$ & Analyte & $\begin{array}{l}\text { Product-Based } \\
\text { Retention }(\%)\end{array}$ \\
\hline Al & 99.41 & Mo & 80.72 \\
\hline$B$ & 87.51 & $\mathrm{Na}$ & 87.12 \\
\hline $\mathrm{Ba}$ & 99.92 & $\mathrm{Ni}$ & 97.99 \\
\hline $\mathrm{Ca}$ & 99.83 & $P$ & 98.19 \\
\hline $\mathrm{Cr}$ & 76.86 & $S$ & 48.88 \\
\hline Cs & 65.18 & $\mathrm{Si}$ & 99.88 \\
\hline $\mathrm{Fe}$ & 99.20 & Sr & 99.00 \\
\hline $\mathrm{K}$ & 62.38 & $\mathrm{Ti}$ & 98.90 \\
\hline $\mathrm{Li}$ & 98.59 & $\mathrm{Zn}$ & 100.00 \\
\hline $\mathrm{Mg}$ & 99.57 & $\mathrm{Zr}$ & 99.90 \\
\hline $\mathrm{Mn}$ & 97.86 & $F$ & 60.81 \\
\hline & & $\mathrm{Cl}$ & 19.15 \\
\hline
\end{tabular}

* (Analyte in Glass)/(Analyte in Glass + Offgas)

The loss of boron, and resulting sodium losses, from the formulation in this application recommends one to the use of non-boron containing formulations. At least one of the initial formulations provided to vendors did not contain added boron.

The plasma melter has shown the capability to process high melting temperature glass. As such, uncertainties with regard to boron loss and total sodium recycle may best be addressed with higher melting temperature soda lime silicate glass formulations.

\subsection{FEED ALTERNATIVES}

During Phase I testing, WSTC conducted melts with prepared frits. The g7ass melted was prepared as -80 mesh material. The small particle size of the frit allows the reactions and glass melting processes to proceed to apparent completion within the narrow time of plume residence ( $15-50 \mathrm{~ms})$. The small particle size will contribute to entrainment; however, of more immediate concern is the issue of economics of melter operation.

Should one consider operating a radioactive plasma vitrification facility with frit, a benefit derived is that the frit is prepared in a nonradioactive 
Table 6: Phase I GTass Formulation

\begin{tabular}{|l|c|c|}
\hline $\begin{array}{l}\text { Vitrified } \\
\text { Species }\end{array}$ & $\begin{array}{c}\text { Glassformer } \\
\text { Composition }\end{array}$ & $\begin{array}{c}\text { Glass Product } \\
\text { Composition }\end{array}$ \\
\hline $\mathrm{SiO}_{2}$ & $57.20 \%$ & $42.90 \%$ \\
\hline $\mathrm{Al}_{2} \mathrm{O}_{3}$ & $19.44 \%$ & $17.77 \%$ \\
\hline $\mathrm{Na}_{2} \mathrm{O}$ & & $18.12 \%$ \\
\hline $\mathrm{B}_{2} \mathrm{O}_{3}$ & $12.60 \%$ & $9.45 \%$ \\
\hline $\mathrm{CaO}$ & $6.20 \%$ & $4.65 \%$ \\
\hline $\mathrm{ZrO}_{2}$ & $2.80 \%$ & $2.10 \%$ \\
\hline $\mathrm{K}_{2} \mathrm{O}$ & & $1.44 \%$ \\
\hline $\mathrm{Li}_{2} \mathrm{O}$ & $1.10 \%$ & $0.83 \%$ \\
\hline $\mathrm{Fe}_{2} \mathrm{O}_{3}$ & $0.66 \%$ & $0.50 \%$ \\
\hline $\mathrm{SO}_{3}$ & & $0.21 \%$ \\
\hline $\mathrm{P}_{2} \mathrm{O}_{5}$ & & $0.19 \%$ \\
\hline $\mathrm{Cs}_{2} \mathrm{O}$ & & $0.15 \%$ \\
\hline $\mathrm{MoO}_{3}$ & & $0.15 \%$ \\
\hline $\mathrm{SrO}_{3}$ & & $0.11 \%$ \\
\hline $\mathrm{Cr}_{2} \mathrm{O}_{3}$ & & $0.04 \%$ \\
\hline $\mathrm{MgO}$ & & $0.002 \%$ \\
\hline $\mathrm{MnO}_{2}$ & & $0.002 \%$ \\
\hline $\mathrm{NaF}$ & & $0.64 \%$ \\
\hline $\mathrm{NaCl}$ & & $0.59 \%$ \\
\hline $\mathrm{NaI}$ & & $0.16 \%$ \\
\hline & & \\
\hline
\end{tabular}

facility. However, the penalty is that one is spending the energy of reheating the glass to several thousand degrees Kelvin, and the process flexibility (glass formulation) exhibits a large time constant for feedback control of the product.

If the operation is conducted with batch materials, material entrainment may be expected to increase while energy demands and total operational cost decrease. However, it may be expected that a longer plume residence is required for complete reaction. Such plume residence time may be increased by reducing mass flow to each torch, and increasing the number of total torches and melters on the plant floor to about 40 torches and 4 melters.

If deployment of plasma vitrification is further considered, batch material testing should be addressed in order to fully evaluate the impact upon facility design. 
WHC-SD-WM-ER-434, Revision 0

\subsection{MAINTENANCE AND OPERABILITY}

During phase I tests, WSTC conducted their melter operations in the manner in which commercial metal refining operations are conducted. That is, the operation was relatively a hands on activity. Observation of the equipment and activities conducted during the melting operations lends credence to the capability of this system to operate and be maintained in a remote configuration. Although many design details of a specific facility must be addressed to provide plasma vitrification remote operation and maintenance, no show stopper issues are seen at this time.

\subsection{FEED HANDLING AND MIXING}

Feed handling and mixing for plasma vitrification operations at WSTC were conducted by positive feed of both glass frit and waste simulant. Some question remains with regard to frit feed calibration during the conduct of the demonstration test; however, feed handling and mixing would generally apply equally well as in a radioactive facility. The major wear component of the feed system is the frit pump. In a radioactive facility pump replacement may be considered to be a moderate outage unless the pump in nonradioactive service. Such service may be acquired if the glass frit or batchformers are slurried with a small amount of water and only admixed with the waste solution after entry into the melter cel1. Uncertainties with such a feed system may be easily resolved with minor testing. 
WHC-SD-WM-ER-434, Revision 0

\subsection{DESCRIPTION OF THE TECHNOLOGY AND ITS APPLICATION}

The following provides a brief description of the concept, test facility, tests, and projections for deployment of the technology.

\subsection{DESCRIPTION OF PLASMA VITRIFICATION}

The Westinghouse Plasma Melter is the basis for the vitrification process proposed by Westinghouse STC for Hanford's low-level waste. The overall process is relatively simple and involves no required pretreatment of the waste other than evaporation to improve efficiency. The WSTC Waltz Mill Plasma Center contains the facility where tests for this program and prior calcination activities occurred.

The Plasma Melter is 6.7 meters in height with an outer she11 diameter of 1.2 meters, refractory 7 ined to provide a 7.6 meter internal diameter.

Refractory in the shaft has been a high-alumina material (91\%), while crucible refractory has been high-chromia material. The crucible is mounted to the bottom of the shaft. A tap hole at the bottom of the crucible is connected to a spout assembly for glass product removal. Process heat is provided by a Westinghouse non-transferred arc plasma torch. Process gas is injected through the cylindrical electrode gap, carrying the arc downstream. The arc heats this working gas to extremely high temperatures.

The waste, slurried with glass frit or glassformers, is injected into the plasma plume within the tuyere where it undergoes evaporation, calcination, melting, and the subsequent reactions for retention of the waste constituents in the product glass. This gas/solid stream exits the tuyere, further condenses, and impinges upon the glass pool in the crucible. Offgasses proceed up the shaft while the glass product is continuously tapped. The gas rates required to operate the torch are considered small compared to conventional combustion heating.

Additional description, imagery, and data available in the documents contained in the references.

\subsection{PHASE I TEST CONDUCT AND RESULTS}

Phase I testing of the WSTC PI asma Melter for the Hanford LLW Vitrification program was proposed and executed as a series of three scoping tests and one final demonstration test.

These tests were of four, eight, ten, and twenty-six hours duration, respectively. The tests produced approximately 1.26, 2.38, 2.77, and 7.37 metric tonnes of glass product with applied power of $1.65,1.53,1.55$, and 1.55 MW, respectively. Each of these tests, their configurations, conduct, and results are discussed below. 
WHC-SD-WM-ER-434, Revision 0

\subsubsection{First Scoping Test}

The first scoping test was conducted on 0ctober 13, 1994. The run was initially cool, but proceeded smoothly for four hours after glass pour became free. Waste feed at 1 gallon per minute and glass feed ( -80 mesh) at $9.3 \mathrm{lbs} /$ minute were slurried and auger fed into the plasma tuyere. Approximately 2780 lbs of glass were poured. Scoping test configurations were reconsidered in light of this success and sodium capture in the waste.

\subsubsection{Objectives}

The first scoping test was to be subdivided into a subtest $A$ and subtest $B$. The subtest $A$ conditions were to be those of an open shaft as depicted in Figure 1.

Subtest $A$ was to be fed with waste slurried with -80 mesh frit provided by Cataphote to specifications provided by Westinghouse Savannah River Company. The objectives of this test were to provide initial demonstration of the feasibility of mixing and injecting the waste and frit slurry, provide initial evaluation of sodium retention in the glass product while operating in open shaft mode, and to analyze heat retention and removal with regard to long duration testing.

Subtest B was to operate with coke in the shaft while firing the glass (as beads) and waste slurry. Subtest B was thus considered as a test for additional material capture and retention with the coke bed

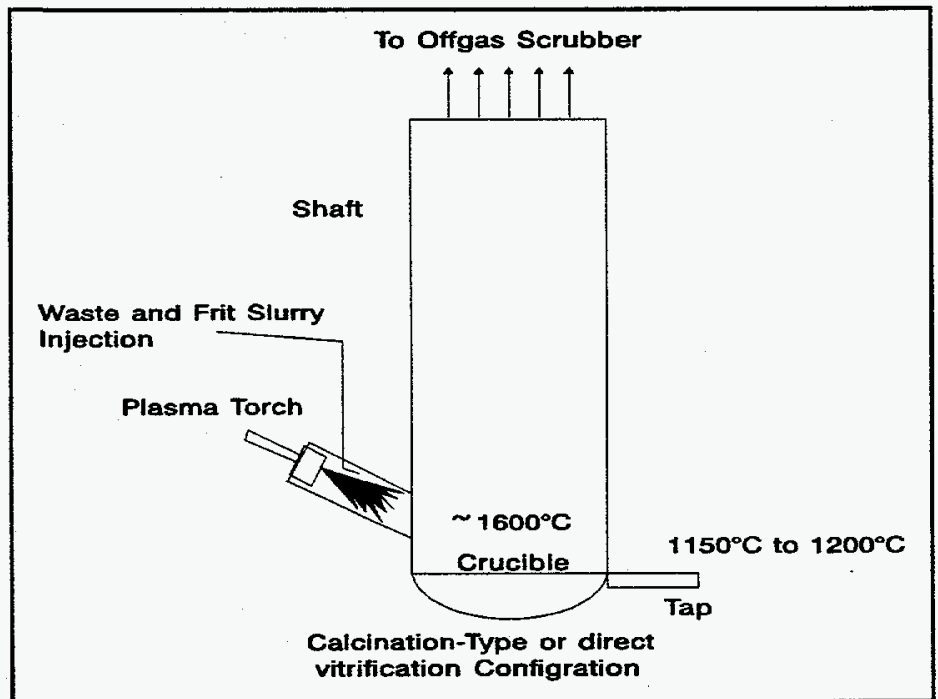

Figure 1: Westinghouse Science and Technology Plasma Vitrification Melter analogous to the batch blanket capture and retention of materials in more conventional melters. Additionally, this subtest was desired for evaluation of heat removal requirements due to the afterfiring of water gas reaction products, and reduction aspects of the coke bed $(\mathrm{e} . \mathrm{g}$. desire of reduction for technetium capture).

\subsubsection{Configuration and Conduct}

Figure 1 provides a simple sketch of the configuration of the melter during the first scoping test. The waste simulant and frit were forward fed by a dual diaphragm pump and auger, respectively, to a hopper atop an open throat 
WHC-SD-WM-ER-434, Revision 0

Moyno ${ }^{2}$ progressing cavity pump. The Moyno pump, with a recycle 1 ine capability, injected the waste slurry into the tuyere and the plasma plume. offgasses proceeded up the shaft, a prequench was conducted and the gas scrubbed in a venturi scrubber. The gas then proceeded through a demister, regenerative fan, and exited the stack. Scrubber liquor was cooled by passing through exchanger plates and was recycled to a $15.0 \mathrm{~m}^{3}$ capacity scrubber liquor tank.

A hopper and sight glass on the hopper were fabricated by WSTC for simultaneous injection of waste simulant and glass frit into the Moyno pump.

On October 12, 1994, WSTC personnel mounted and prepared the plasma torch and completed all interlock clearances at 16:55. The crucible had been filled with 600 lbs of coke to preheat the refractory overnight. The torch was ignited at 17:00 but later exhibited a breaker board failure. The torch power supply failure was rectified by 8:30 a.m. on October 13, 1994. The supply failure (diagnosed as one of three series switches) resulted in incomplete burnout of the coke and low refractory temperatures at the initiation of the scoping test $\left(\mathrm{ca} .450^{\circ} \mathrm{C}\right)$.

Throughout the 12th and morning of the 13th, system calibrations occurred with curve creation for simulant feed rates, frit feed rates, torch and shroud gas rates.

Slurry feed began at 11:50 a.m. on October 13, 1994, at $1000 \mathrm{~kW}$ having been preheated at $800 \mathrm{~kW}$. Sodium volatilization, evidenced at the top of the shaft, drove the operation to full frit feed within ten minutes and power to $1.5 \mathrm{MW}$. At this point, sodium volatiles were no longer observed. 0xygen lancing of the tap hole began at 12:00 to attempt to clear the tap. Such lancing is not practiced in commercial glass manufacture; it was jointly determined that the exhibited need for lancing was due to the cool tap area. Insulating board was placed over and within the spout of the tap. By 12:40, the glass was freely flowing out of the tap.

With stabilization, the shroud gas flow rate was $8.5 \mathrm{~m}^{3} / \mathrm{min}(300 \mathrm{scfm})$ and torch gas at $4.5 \mathrm{~m}^{3} / \mathrm{min}(160 \mathrm{scfm})$. The run continued until $4: 00$ when glass and waste simulant flow were discontinued and water run through the slurry feed line to the torch to rinse out the auger and feed lines.

On the morning of October 14, 1994, the crucible was taken down and plasma torch removed from the tuyere. It was observed that some of the coke from pretest heating remained on the floor of the crucible; most of the coke appeared unwetted by the glass remaining in the crucible. Some iron nuggets from reduction of the coke ash were found under the coke. The glass flow path clearly indicated that no extensive residence time existed prior to exit directly out the tap. The crucible refractory (ruby plastic) showed no signs

${ }^{2}$ Moyno is a trademark name of products manufactured by Robbins and Meyers, Inc., Springfield, OH. 
WHC-SD-WM-ER-434, Revision 0

of damage. The tuyere entrance to the shaft showed clear glass slagging films which ran into the crucible. The shaft wall opposite the tuyere showed additional agglomerations of the material which was believed to be devitrite. Remaining shaft refractory did not display any gross injury and primarily remained blackened by soot from the coke preheating.

\subsubsection{Results}

Preliminary results of $x$-ray fluorescence analys is of glass samples pulled at 1:00 indicated 17.6 and $18.3 \% \mathrm{Na}_{2} \mathrm{O}(+/-1 \%)$ with target composition of $18.12 \%$. These results indicated that concern for sodium volatilization was not merited, rather, retention appeared to be excellent. Later samples, taken after the system had stabilized, demonstrated $15-16 \% \mathrm{Na}_{2} \mathrm{O}$, consistent with $80-$ $90 \%$ sodium retention. Potassium and 1 ithium analyses were to be evaluated for volatilization. Some materials that looked like devitrite had begun appearing in the glass samples with the second of three mold boxes; it was later determined that this material was aluminum oxide crystals from the cast corundum-mullite refractory placed into the tuyere. The glass had solubilized the mullite binder of the corundum.

The test yielded several considerations for improvement including: additional residence time [ $\tau]$ (observed batch reaction offgassing in tap area), observation of residence time, homogeneity (in part, the incorrectly assumed devitrite), glass temperature measurement, and tap heating. Additional residence time (through dams) and homogeneity through bubbling were discussed with bubbling and an embedded inconel clad thermocouple in glass for glass temperature measurement but not elected. The application of dams were elected to enhance fining, and observation of residence time through a feed spike was planned. The relocation of the Moyno pump away from the deck was considered for safet:y purposes, to do so, the chip auger for the frit would need to be removed and remounted in reverse - would require additional frame work to support the auger.

Subtest B of the scoping run, with a coke bed, was postponed and later waived, following discovery of the loss of several thermocouples and pressure

transducers in the shaft. Additionally, nitric acid had traveled up some of the instrument systems because the sample conditioner had been swamped. The shaft wal1, externally cooled by falling water film, had exhibited temperatures of $400^{\circ} \mathrm{C}$ during the run, the water film demonstrated a $23^{\circ} \mathrm{F}$ temperature increase; installation of a shaft baffle and raising the height of the film were to be considered to stabilize the operation. Heat exchange, as the only heat dump other than the recirculating scrubber 1 iquor, was 1 imited to $500 \mathrm{~kW}$; addition of plates was approved to expand capacity to $1 \mathrm{MW}$. The scrubber liquor demonstrated a temperature increase from $60^{\circ} \mathrm{F}$ to $94^{\circ} \mathrm{F}$ for its $13.1 \mathrm{~m}^{3}(3,500$ gallon) volume (500 gallon make up used).

The B subtest was waived in view of the apparent success of the open shaft operation. Safety considerations and heat exchange considerations seconded this waiver: use of a coke bed with the slurry feed results was expected to yield production of extensive quantities of hydrogen through water gas 
WHC-SD-WM-ER-434, Revision 0

reactions with the coke, afterburners required to combust the generated $\mathrm{C} 0$, $\mathrm{H}_{2}$, and $\mathrm{H}_{2} \mathrm{~S}$ would consume most of the heat removal capability of the system.

\subsubsection{Second Scoping Test}

Following the high sodium retention of the first scoping test, the second scoping test was scheduled for October 26, 1994, in an open shaft mode. The second scoping test was delayed one week due to late delivery of heat exchanger expansion and late delivery of reground glass. Upon conduct of scoping test on November 3, 1994, the scoping run was deemed fully successful with chemical analyses pending.

\subsubsection{Objectives}

The second scoping test was prepared to include the following aspects:

- Longer open shaft test - 8 hours

- Radiation baffle in shaft to minimize thermal excursion up the shaft

- $\quad S 1$ ag dam in tap area to increase residence time [ $\tau]$

- Installation of a tap hot box to insulate the tap area

- $\quad$ Preheat of refractory without coke - gas burners overnight followed by torch ignition

- Expanded HX to $1 \mathrm{MW}$ (1 imit of current exchanger)

- Additional sample conditioner capability

- No relocation of the Moyno yet, but creation of a bigger hopper and bridge breaker planned.

\subsubsection{Configuration and Conduct}

The configuration of the test was as described in \$5.2.1.2 and depicted in Figure 1. A radiation baffle was installed in the shaft. The run was conducted at 10\# $\mathrm{glass} / \mathrm{min}$ for $1 \mathrm{gpm}$ (Continued with rates from last time).

Frit supply was to be made by Ferro upon regrinding of glass beads prepared by Cataphote. The glass beads were to be used in coke mode firing of the plasma vitrification unit; upon successful operation in the open shaft mode in the first scoping test, it was determined that subsequent scoping tests would also be conducted in open shaft mode. The glass bead was found to be too well tempered to be ground in the $1000 \mathrm{lb} / \mathrm{hr}$ l" ball mill of Ferro. An experimental $2^{11}$ ball mill was applied with the resulting grind rate of 20-30 $1 \mathrm{~b} / \mathrm{hr}$; grinding of the $5,000 \mathrm{lb}$ of glass bead was estimated at $200 \mathrm{hr}$.

Conduct of the second scoping test was delayed one week to provide sufficient time for Ferro to deliver the frit, for the heat exchanger $\mathrm{plates}$ to be added, and to allow for the presence and support of P1asma Center technicians. The delay was mandatory to have enough glass frit available for a longer test; a longer test was necessary to evaluate operational stability and thermal excursion remediation, a primary objective of the test. 
WHC-SD-WM-ER-434, Revision 0

WSTC did run the second scoping melt on November 3, 1994, for a full 8 hours until out of glass frit supply. Approximately half-way through the run, the glassformers changed over to the material reground by Ferro. Two oxygen lances were used to initially clear the tap, but for the remainder of the time, the glass "ran like water." The radiation baffle worked well and reduced energy requirements; they were able to run stably at $1525 \mathrm{~kW}$.

\subsubsection{Results}

The radiation baffle installed to limit thermal excursion performed admirably allowing reduced power input while retaining radiative heat in the lower area of the shaft. Unfortunately, the valve providing air to cool the chain and upper surface of the baffle fouled (too small diameter) with the consequence of softening much of the baffle and chain link failure late in the run. The baffle fell to the crucible inducing some refractory damage enroute.

Target sodium oxide loading in the glass was $19.6 \mathrm{wt} \%$. Test samples indicated that acquired loading was $19.2 \mathrm{wt} \%$.

WSTC did run a barium spike for residence time analysis. Subsequent analyses indicated operations and retention were well represented as two differently sized continuous stirred tank reactors in series (crucible and tap) with a total mean residence time of 31 minutes. The curve width for residence time looks to agree well with weir $\left(3^{\prime \prime}\right.$ in spout) $+8^{\prime \prime}$ fluid flow head at 200 Poise (P). See Figure 2.

The assembly of a doghouse of refractory board around the tap significantly eased the continuous pouring operations.

The $\mathrm{NO}_{\mathrm{x}}$ analyzer was difficult to keep on line - up $70 \%$ with 7-8 fixes. Sample conditioner increase did heip, but did not entirely resolve problems.

The tuyere refractory, left in place, was profiled before and after test. Tuyere refractory did not evidence significant losses during the second scoping test except in the zone of direct impingement of the plume. The rate of loss was noted to have decreased by $65 \%$ over the first scoping test, leading to an assumption to an approach to Barium Tracer Residence Time Test Trial Heat \#2 - November 3, 1994

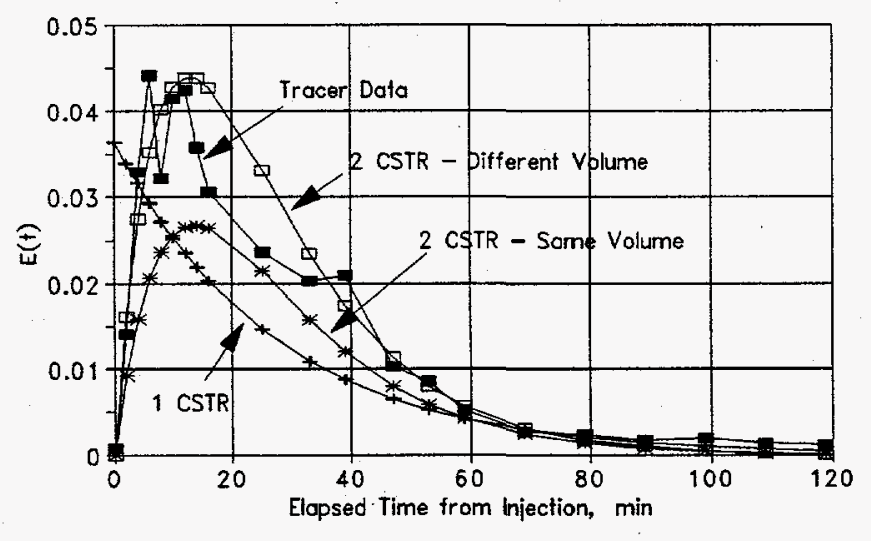

Figure 2: Barium Tracer Evaluation of Residence time steady state. Shaft refractory (PC Ram 90: 91\% alumina, 5\% silica, 3\% P205) patches demonstrated some peeling, new material showed little to no damage. 


\section{WHC-SD-WM-ER-434, Revision 0}

The bottom of crucible left with smooth glass pool (lighter in color), clear green to yellow, very transparent - very few "rice grains" [corundum crystals from tuyere refractory] (tuyere losses lower). On top of pool were fragments of refractory - partially vitrified - part from baffle plate.

Stainless steel thermocouples lived about 5 minutes. Three thermocouples were also present $1 / 8$ " below the surface of the refractory in crucible area. The steel thermocouples did evidence glass temperatures approximately $30^{\circ} \mathrm{C}$ higher than read by the immersion thermocouple.

\subsubsection{Third Scoping Test}

The third scoping test was deemed fully successful, melting for ten hours and shutting down only when waste simulant ran out. Approximately $2,770 \mathrm{~kg}$ $(6,100 \mathrm{lb})$ of glass was produced, with a glass melt temperature retained at approximately $1250^{\circ} \mathrm{C}$ and stable power input of $1550 \mathrm{~kW}$. Additional details are provided below.

\subsubsection{Objectives}

The stated objectives of the third scoping test were to test the modified waste feed system including a larger waste feed tank, immersion heater, pump, relocated chip auger, relocated Moyno pump, and to provide on-the-job training (OJT) for additional technicians required for the shift work inherent with the upcoming 30-hour test. It was to be conducted in the configuration depicted in Figure 3.

\subsubsection{Configuration and Conduct}

A new baffle plate (the last of $304 \mathrm{~S}$ was thoroughly melted) with internal air cooling and refractory (ruby plastic) had been fabricated and prepared for installation; additionally, a larger air feed valve was installed.

The third scoping test was pushed to November 17, 1994. The one day delay is due to incomplete parts receipt for the operation of the larger waste feed tank (plumbing). This delay was insufficient to get the new feed system on line. Thus, the test was conducted in the configuration depicted in Figure 3 with the

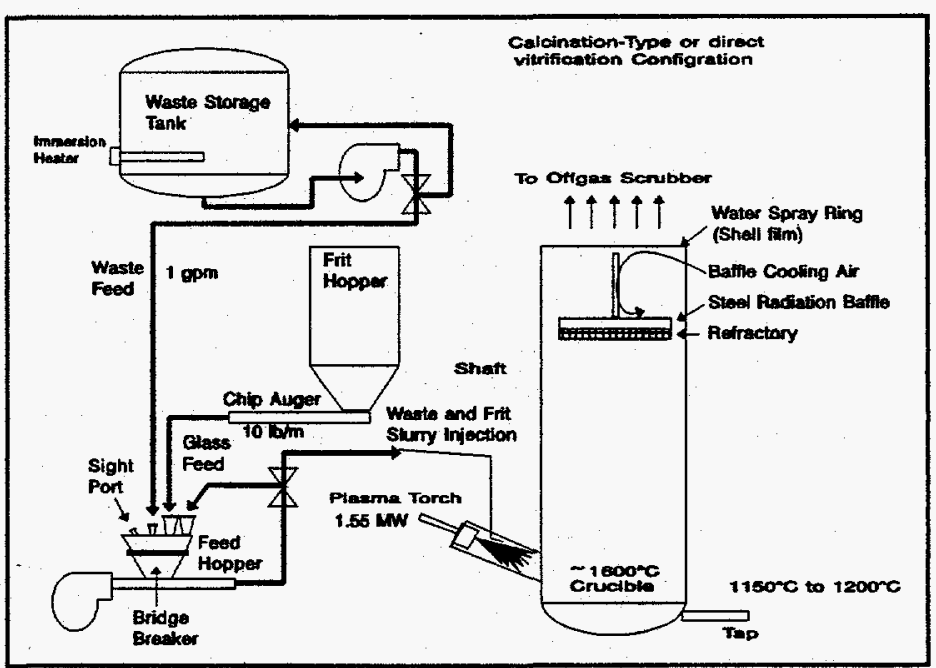

Figure 3: WSTC Plasma Vitrification Melter Configuration. 
WHC-SD-WM-ER-434, Revision 0

exception of the liquid feed system, which continued to feed from previous tankage.

On the morning of November 16, 1994, the glass frit was loaded for the initiation of the scoping test (additional frit required to be loaded during test due to storage capacity limit). Plans were made to initiate the run with a methane supplement to the plasma shroud air to attempt to reduce $\mathrm{NO}_{\mathrm{x}}$ generation.

The furnace was preheated with methane burners overnight on $11 / 16-17 / 94$, then heated with the plasma torch from $\sim 8: 00$ a.m. Glass feed was initiated at 10:00 (1arge diameter of chip auger and frit feed line yielded frit visibly arriving at the pump at 10:07. The crucible temperature at this time was $1136^{\circ} \mathrm{C}$. Molten glass was seen in the tap at 10:28 with free flowing glass at 10:33. Some sodium fuming had previously been noticed in the upper reaches of the furnace shaft. Due to the $0.6 \% \mathrm{Fe}$ in the frit, the glass appeared browngold and green with some of the $\mathrm{Al}_{2} \mathrm{O}_{3}$ crystals from the tuyere refractory (same matterial used in all three scoping runs without replacement).

An air purge modification on the frit feed hopper significantly reduced material bridging while the bridge breaker is still in fabrication.

Figure 4 depicts temperature profiles of the system during the early hours of operation. The upper data series is the glass temperature. The remainder of the operation, as indeed the initiation, ran smoothly and without incident. Temperature profiles of the crucible, tap, and glass were closely monitored to enable reduction of power.

Scrubber liquor stabilized at $90^{\circ} \mathrm{F}$ and power stabilized at a low average of approximately $1525 \mathrm{~kW}$ with glass temperatures averaging $1250^{\circ} \mathrm{C}$. Glass temperatures as high as $1288^{\circ} \mathrm{C}$ were measured. These were higher than desired and allowed the lower power input.

Additional glass frit was loaded during operation without incident.

At $8: 30$ p.m. waste simulant level in the feed tank had dropped sufficiently to yield

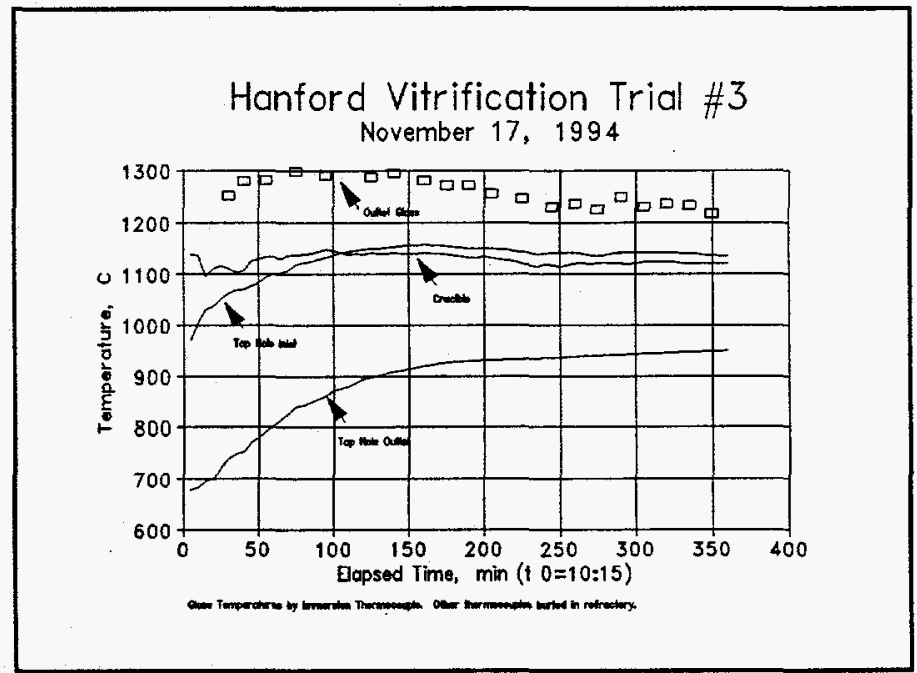

Figure 4: Temperature Profiles upon Plasma Torch Vitrification Initiation instability of the dual diaphragm pump (new feed system has bottom suction and surge repressor for dual diaphragm pump). Waste feed and glass feed were discontinued. System drain continued with torch operation until plasma torch shutdown at 8:46 p.m. 
WHC-SD-WM-ER-434, Revision 0

\subsubsection{Results}

The glass product, as later analyzed, was consistent and in agreement with target glass compositions. Primary component fractions of the product are depicted in Figure 5 and tabulated in Table 7.

Following the test, observations indicated that the baffle plate was still in place. The baffle plate performed the required heat retention without sustaining observable damage.

No obvious additional wear was observed in the tuyere upon post-inspection. A layer of glass was reported in the area of tuyere where it was previously thinned. Apparently refractory erosion and corrosion were significantly reduced (higher heat transfer). Despite the success in wear limitation new tuyere refractory (and the consequent losses) were to be placed for the demonstration run.

During part of the run, the charge door was held partially open resulting in gas cooling and additional deposition in the first bend of the offgas system. This was in part due to a $9^{\prime \prime}$ orifice in the $30^{\prime \prime}$ duct. The deposits and constriction were removed following the run.

With all other feed aspects (new feed system completed soon thereafter) and OJT provision of personnel completed, the facility was determined to be ready to conduct the long duration demonstration test.

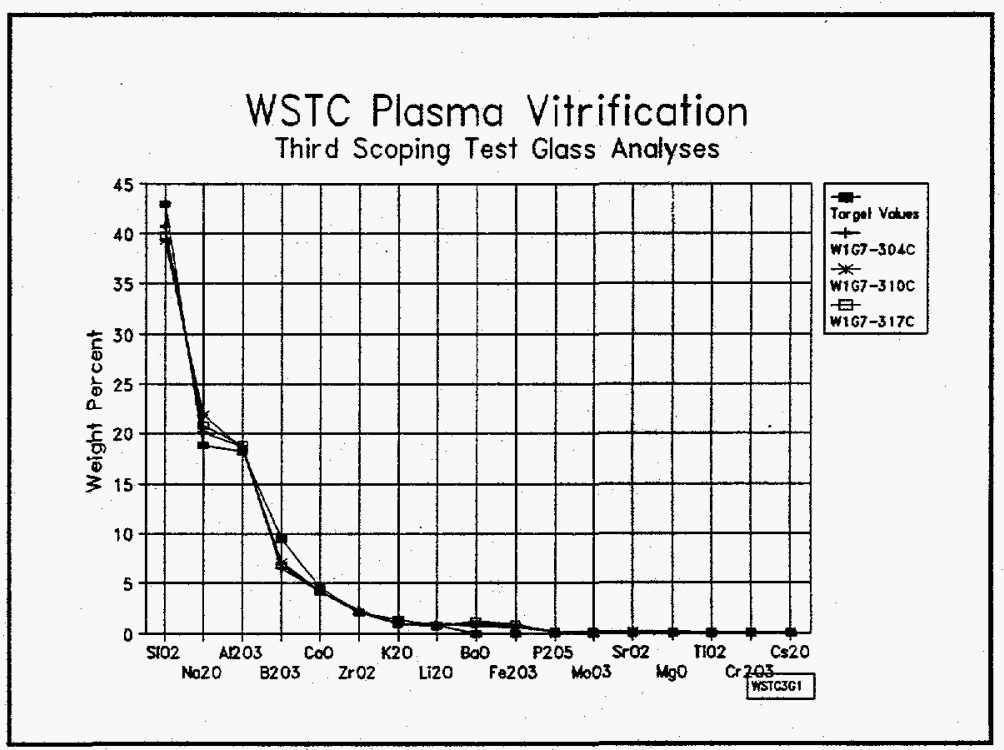

Figure 5: Third Scoping Test Glass Composition

\subsubsection{Demonstration Test}

The final demonstration test configuration was established as depicted in Figure 3 and Figure 6 with the exception that the larger feed system mixer blade was not brought on line. The final demonstration test was deemed fully successful, pending sample analysis, melting for twenty-six hours on December $7-8,1994$. Sixteen and one-half mold boxes $(7,190 \mathrm{~kg})$ of glass were collected with $180 \mathrm{~kg}$ of glass remaining in the melter. Glass temperatures varied from ${ }^{2} 1370^{\circ} \mathrm{C}$ (early) to $1200^{\circ} \mathrm{C}$, averaging $1262^{\circ} \mathrm{C}$. Power inputs ranged from 
WHC-SD-WM-ER-434, Revision 0

Table 7: Third Scoping Test Glass Analyses (Wt\%)

\begin{tabular}{|c|r|r|r|r||}
\hline Sarnple No. & Target Values & W1G7-304C & W1G7-310C & W1G7-317C \\
\hline SiO2 & 42.90 & 40.7 & 39.3 & 39.7 \\
\hline $\mathrm{Na20}$ & 18.82 & 20.1 & 21.9 & 20.8 \\
\hline $\mathrm{Al203}$ & 18.22 & 18.7 & 18.5 & 18.8 \\
\hline B203 & 9.45 & 6.57 & 7.17 & 6.88 \\
\hline $\mathrm{CaO}$ & 4.65 & 4.24 & 4.24 & 4.28 \\
\hline ZrO2 & 2.10 & 2.39 & 2.08 & 2.07 \\
\hline K20 & 1.44 & 0.90 & 1.07 & 0.96 \\
\hline Li20 & 0.83 & 1.05 & 0.78 & 0.77 \\
\hline BaO & 0.00 & 0.76 & 1.07 & 1.24 \\
\hline Fe203 & 0.00 & 0.65 & 0.68 & 0.90 \\
\hline P205 & 0.00 & 0.17 & 0.14 & 0.14 \\
\hline Mo03 & 0.00 & 0.14 & 0.16 & 0.15 \\
\hline SrO2 & 0.00 & 0.096 & 0.089 & 0.082 \\
\hline MgO & 0.00 & 0.093 & 0.039 & 0.030 \\
\hline TiO2 & 0.00 & 0.054 & 0.052 & 0.057 \\
\hline Cr203 & 0.00 & 0.038 & 0.044 & 0.044 \\
\hline Cs20 & 0.00 & 0.022 & 0.032 & 0.029 \\
\hline F- & 0.00 & 0.02 & 0.03 & 0.02 \\
\hline MnO2 & 0.00 & 0.019 & 0.018 & 0.022 \\
\hline NiO & 0.00 & 0.002 & 0.005 & 0.004 \\
\hline
\end{tabular}

$\sim 1.7 \mathrm{MW}$, falling to $1.4 \mathrm{MW}$ with an average of $1.55 \mathrm{MW}$. Additional details are provided below. Photographs taken during the demonstration test are archived, descriptions of the photographs are provided in Appendix $A$.

The test plan for the conduct of the demonstration test was issued by the Westinghouse Hanford Company on December 2, 1994, as WHC-SD-WM-VI-011, Revision 0, Test Plan for Evaluation of Plasma Melter Technology for Vitrification of High-Sodium Content Low-Level Radioactive Liquid Wastes.

\subsubsection{Objectives}

The goals of the demonstration test, as established by WSTC to meet the statement of work (Wilson 1994) are:

1) Operate the vitrification facility in glass production mode for a minimum of twenty-four consecutive hours at steady state, and a target of thirty hours, without significant upsets or outages, and exhibiting overall thermal stability in the glass product, melter shaft, and scrubber system.

2) Produce a glass product having a sodium oxide nominal content of 18-20 weight percent, with consistent quality and reasonably low viscosity at 
WHC-SD-WM-ER-434, Revision 0

a melter operating

temperature of 1150-

$1250^{\circ} \mathrm{C}$, good durability

(as measured by PCT

examination), and $80-90 \%$

sodium capture efficiency.

3)

Collect process data on

flow rates and all

pertinent system

temperatures to permit

construction of an overal1

and a species specific

heat and material balance

following successful test

operations, enabling

engineering scale-up

design efforts to proceed.

4) Demonstrate the ability of

the feed system

(consisting of feed tank,

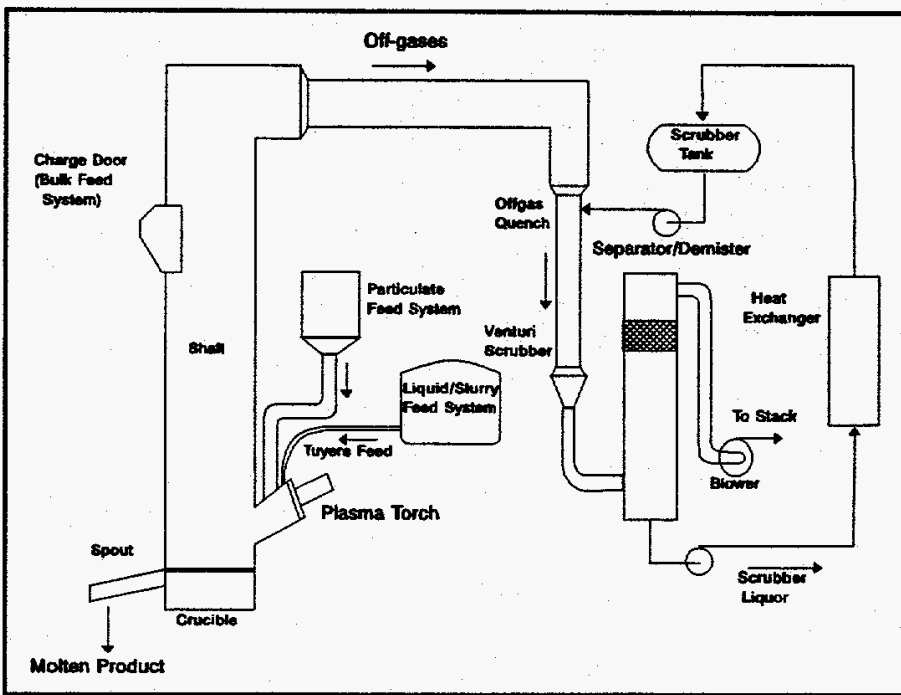

Figure 6: WSTC PTasma Melter and Offgas System Configuration

agitator, heater, diaphragm pump, double loop recirculation system, feed transfer lines, metering valves, glassformer feed auger, Moyno blending pump, and tuyere injection nozzle) to provide uniform, controllable delivery of the simulant-glassformer mixture to the plasma melter.

5) Collect representative samples of all feed, product, and residue materials in accordance with the predetermined sampling $\mathrm{plan}$, to enable material balance closure and good characterization of the products.

6) Characterize the flow and composition of the melter offgasses as post of the species material balance, both by on-line gas analysis instrumentation and grab sample analyses.

7) Characterize the durability of the refractories used, based on examination and dimensional profiling both before and after the test, to assess the suitability of the various compositions to withstand the plasma vitrification environment over long-term exposure.

\subsubsection{Configuration and Conduct}

On December 6, 1994, pretest preparations included detailed electrode measurements to evaluate wear, feed system calibrations, gas sampling system calibrations, crucible refractory firing, and completion of waste feed loadout. Previously completed were profiling of shaft and crucible refractory and replacement of tuyere refractory with virgin material. The scrubber liquor tank had been cleaned and filled with 3,500 gallons of city water. The feed pump (Moyno) that had been leased was replaced with the purchased pump and the bridge breaker and larger feed hopper installed.

It must be noted that waste simulant feed received from Optima was observed to contain approximately 24 vol\% solids. Feed loadout for WSTC involved three operations: Liquid pumping from each drum; removal of drum liners and individually dumping solids into the feed tank; and, rinsing and dumping of 
WHC-SD-WM-ER-434, Revision 0

remainder of each drum into the feed tank. The last two operations required a forklift operator and two operators in full chemical protective gear to

individually handle each drum. At this time it is not yet understood why this waste feed material differed so much from the first simulant batch in handling characteristics. Due to the large quantity of solids and concerns of blinding, the filter on the tank side of the feed line was removed. Although the feed was recirculated and heated overnight, this may not have been sufficient to redissolve and resuspend more than about half of the observed solids..

Following seal placement, the crucible was mounted to the shaft and the system was fired with methane torches overnight to preheat the refractory.

On December 7, the plasma torch was 1it at 9:07 a.m. at a power of $810 \mathrm{~kW}$. Power input continued at levels increasing to $1500 \mathrm{~kW}$. The test formally began with waste feed initiated at 12:55 p.m.

Several specific observations during the test conduct dealt with operation of the offgas handling system. The physical piping for the train is depicted in Figure 7 while the remainder of the treatment system is shown in Figure 6 .

As described above, waste and frit slurry feed initiated at 12:55 p.in. Glass product began flowing, without oxygen lancing, from the tap at 1:30 p.m. at a temperature of $1370^{\circ} \mathrm{C}$. Some minor fuming was seen from the glass stream with the conjecture

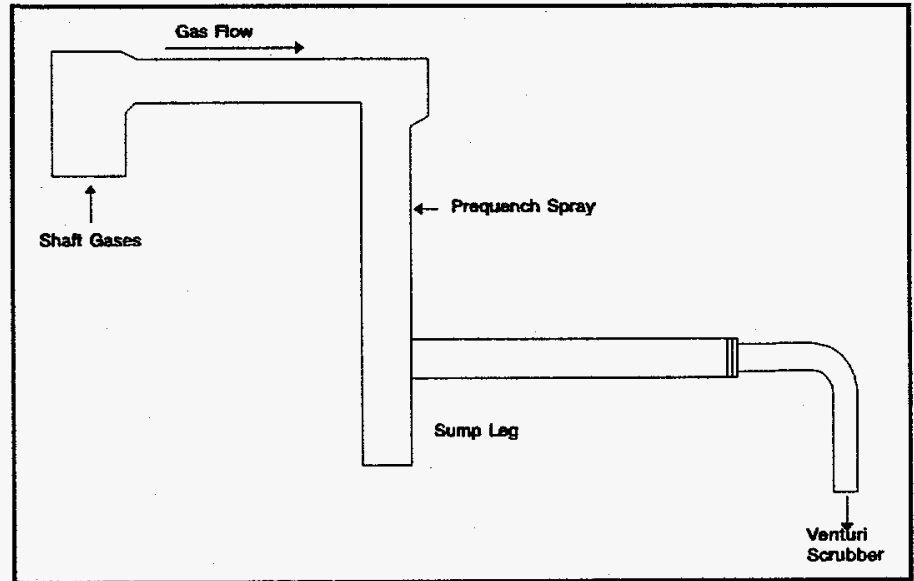

Figure 7: WSTC Offgas Train Piping Arrangement that it was sodium borate.

Glass flow proceeded well with no evident operational difficulties, exhibiting the stability of the plasma torch operation. The first of two glass mass flow rate samples was taken at 3:57 p.m. After sufficient time to allow handling, the mass flow rate was found to be $77.95 \mathrm{~g} / \mathrm{s}(3.57 \mathrm{~kg} / 45.8 \mathrm{~s})$. With approximately $408 \mathrm{~g} / \mathrm{L}$ of waste oxides, and feed rates of $4,545 \mathrm{~g} / \mathrm{min}$ frit and $3.78 \mathrm{~L} / \mathrm{min}$ waste simulant, the production rate should have been $101.5 \mathrm{~g} / \mathrm{s}$. This indicated a discrepancy of $23.2 \%$. Conjectured as the cause was the $10 s s$, by volatilization, of sodium borate and halides. This discrepancy was not correlated to the overall material balance and species balances. Observations and samples of scrubber liquors and the remainder of the offgas train were highlighted by this concern through the remainder of the demonstration. The glass sample pulled from the first mass flow rate measurement was later shipped to Prof. Micha Tomkiewicz (Dept. of Physics, Brooklyn College of the 
WHC-SD-WM-ER-434, Revision 0

City University of New York) for electrochemical probe development work supporting Hanford LLW Vitrification Quality Assurance.

Sample acquisition and documentation appeared to run smoothly throughout the test.

Oral reports indicated that overnight operations proceeded smoothly with only one minor system interlock shutdown. At one point during the night the breaker for the chip auger (feeding the glass frit to the feed hopper) tripped. Safety system interlocks shut down the chip auger for the ten minutes or so it took to clear and restart the chip auger.

Beginning at approximately 11:00 a.m. on December 8, 1994, fuming and apparent back "puffing" from the charge door began to cloud the upper reaches of the building. It was believed that this was being caused by some restriction of gas train. Operations staff found that a back pressure was occurring (differential pressure cells) in the area of the venturi scrubber. At approximately 12:25 operators and the facility engineering manager tapped ducting causing some material to break free (audibly) and enter the separator. It appears that some of this material was entrained and partially blinded the heat exchanger causing the separator level to rise and the offgas blower to overamp. The blower overamperage caused the safety system interlocks to shut down the torch and feed (separator, heat exchanger, and blower primary functions are heat and particle removal) at 12:57 p.m. Within 25 minutes the crew had cleared the separator and had the torch and feed back on line. Due to the blinding, the heat exchanger was taken off line; the loss of heat removal from the scrubber liquor would require that overall test length be reduced to prevent the scrubber liquor for exceeding acceptable temperatures. Glass was flowing again within 20 minutes of torch and feed restart. It is noted that the shutdown described was not due to failure of the plasma technology but to an inadequacy in the offgas handling subsystem.

At 3:00 p.m. on 12/8/94, waste feed and glass feed were discontinued (water brought on line to replace the waste) and the doghouse (insulation material around the glass tap) was removed. The tap was bottom drained and glass flow soon discontinued completing the demonstration with a controlled shutdown.

At $6: 30 \mathrm{p} . \mathrm{m}$. on 12/8/94 the torch was removed and the tuyere opened. It was observed that some material accumulations existed within the tuyere in the area of the removed torch. Torch and glass wear of the tuyere refractory was observed to be deflected to the right of the nominal torch plume center. It is believed that the material deposition (probably sodium borate as it did not significantly hydrate overnight like caustic would) caused the shroud air to be deflected causing redirection of the plume and stream mixing. Nominally, the shroud gas, tangentially fed, protects the tuyere refractory by creating a cool gas boundary. Overall tuyere wear was much less than anticipated, it was observed that a glass skull had formed in the area of greatest refractory wear within the tuyere. 
WHC-SD-WM-ER-434, Revision 0

Continued system ventilation to cool the refractory yielded material fragments cascading audibly through the lower horizontal segment of the offgas train (see Figure 7) toward the venturi.

On the morning of December 9, 1994, the crucible was removed. Photographs were taken of upward drilling in the shaft refractory near the apparent liquid line and other aspects of appearance of the refractory and material remaining in the crucible. Little to no damage of the crucible refractory was observed. The radiation baffle in the shaft was in very good condition.

The sump leg on the offgas leg was drained, yielding approximately 25 gallons of sludgy liquid. Because the leg had not been drained during the last several years of operation, the materials in the leg were anticipated to be of various sources. Samples were acquired for analysis.

During the Tate afternoon of December 9, 1994, the shaft refractory had been cooled sufficiently to allow visual observation of the upper shaft and upper horizontal section of the off-gas ducting. No significant buildup was observed in the shaft of the bend (see Figure 7). However, the upper horizontal duct (circular cross-section) appeared to be filled to a depth of 3 " to 4". This material was believed to be sodium borate and potentially account for a large fraction of the material imbalance described above.

Discussions held at that time pointed toward elimination of the boria from the frit; the sodium borate is much more volatile that the sodium by itself, hence elimination of the boria would yield greater retention of the sodium.

Sample selection for analysis proceeded on $12 / 9$ and $12 / 10$ with no apparent and significant difficulties.

\subsubsection{Results}

The following responds to acceptance criteria described above ( $\S 5.2 .4 .1)$ :

1) The vitrification demonstration test was carried out successfully. The test ran for a total of 26 hours, with steady-state production of molten glass product for 24 of those hours. The mean throughput was approximately 7.1 tonnes/day, producing $7,370 \mathrm{~kg}$ of glass product. Peak-hourly production was $6.2 \mathrm{~kg} / \mathrm{min}$ ( 9 tonnes/day). Average electrical power of $1550 \mathrm{kWe}$ was applied with average energy consumption over the entire melting operation being $19.4 \mathrm{MJ} / \mathrm{kg}$.

2) The glass product was free-flowing at a spout immersion temperature of $1262^{\circ} \mathrm{C}$. Theoretical soda content with zero volatility loss) should have been 22 wt\%. Sodium volatilization was recognized as occurring, particularly in the form of sodium borate compounds; hence soda content will be less than theoretical. This content has been quantified by chemical analysis at $19.9 \%$ average $\mathrm{Na}_{2} \mathrm{O}$, corresponding to a sodium $10 \mathrm{ss}$ in the of $13 \%$.

3) Process data were collected from all data sampling locations identified in the test plan (WHC-SD-WM-VI-011), with the bulk of the data routed directly to the process datalogging computer system. These data have 
WHC-SD-WM-ER-434, Revision 0

been downloaded to Quattro Pro $^{3}$ spreadsheets, combined with manual data collection results, and are currently being processed for initial heat and material balance assessment.

4) The feed system was capable of providing stable simulant-glassformer feed rates to the melter for the entire melting operation. The only substantial feed delivery issue concerned the simulant itself which contained substantially higher total solids than was expected based on prior experience. The impeller was not operated on the feed tank due to electrical incompatibilities hence some concern of resuspension exists. Actual uniformity of waste solids in the melter feed will be determined by analysis of feed slurry samples.

5) Samples were collected of the waste simulant, glassformer frit, fritsimulant feed slurry, glass product, offgasses, offgas aerosols/entrained particles, and scrubber water at regular intervals during the test in accordance with the test plan. Samples were forwarded to the analytical laboratories, albeit with some minor quantifiable and rectifiable errors and confusion.

6) Samples were collected of offgas and entrained aerosol material at regular intervals according to modified EPA Method $5^{4}$ procedures with analysis to be carried out by a contract laboratory. On-line gas analyzers sensitive to $\mathrm{CO}, \mathrm{CO}_{2}, \mathrm{H}_{2}, \mathrm{O}_{2}$, and $\mathrm{NO}_{x}$ yielded data collection for minimum of $86 \%$ of the run ( $\mathrm{NO}_{x}$ analyzer suffered one outage).

7) Examination of the tuyere refractory (alumina-calcium aluminate) showed significant thinning although less than was observed during the cumulative operations of the scoping heats. Cooling water temperature profiles do not indicate continued thinning after several hours operation (e.g. heat loss does not accelerate any more) indicating that the refractory thickness had achieved a near steady-state value supported by formation of a cold skull glass coating. Preliminary examination of the ruby refractory in the crucible and on the baffle plate showed no obvious damage or loss.

The glass product composition, as later analyzed, is depicted in Figure 8 , and Table 8. As evidenced, the product was consistent through the test and was in agreement with the target glass composition.

Leach results of the product glass (Table 9) indicates that product durability significantly exceeded requirements specified in the statement of work (Wilson 1994) of $1 \mathrm{~g} / \mathrm{m}^{2} /$ day normalized sodium 7 each.

\footnotetext{
Valley, CA.

Quattro Pro is a trademark of Borland International, Inc., Scotts

4 see 40 CFR Part 61, Appendix A, Method 5
} 
WHC-SD-WM-ER-434, Revision 0

\subsection{PRODUCT QUALITY AND PRODUCTION RATE}

Quality

\subsubsection{Product}

Product quality requirements have not been finalized for the Hanford Low-Leve1 Vitrification facility. However, interim requirements for testing purposes were established (Wilson 1994) as a normalized sodium leach of $1 \mathrm{~g} / \mathrm{m}^{2} /$ day. No appearance qualities have been established; however, the existence of seed and string in the glass product would be indicative of inhomogeneities and devitrification. Such inhomogeneities and devitrification would tend to result in lower durability.

The quality of WSTC product glass as evidenced by leach characteristics (Table 9) exceeds the durability requirements by factors of twenty to seventysix for sodium leach. Observation of the glass product noted obvious bubbles from retention of gasses within the glass, but such bubbles are not anticipated to be of any consequence.

Some seed and minor devitrification (often $<<1 \%$ ) was observed. It was noted that on at least one occasion, the seed contained a high chromia-alumina core indicative of a particle of refractory providing a nucleus for devitrification. Overall, seed and string in the glass product was minimal.

Table 9: Demonstration Test Glass PCT Leach Analyses

\begin{tabular}{||c|c|r|r|r|r|r||}
\hline Sample No. & (unit) & W1G07-404C & W1607-412C2 & W1607-419C3 & W1607-425C4 & W1G07-425U4 \\
\hline PCT Leachate & $\mathrm{pH}$ & 11.2 & 10.5 & 10.8 & 10.8 & 11.3 \\
\hline Si (PCT) & (g/m2-day) & 0.016 & 0.012 & 0.017 & 0.010 & 0.012 \\
\hline B (PCT) & (g/m2-day) & 0.020 & 0.017 & 0.028 & 0.049 & 0.020 \\
\hline Na (PCT) & (g/m2-day) & 0.022 & 0.013 & 0.027 & 0.044 & 0.050 \\
\hline K (PCT) & (g/m2-day) & 0.015 & 0.011 & 0.022 & 0.029 & 0.017 \\
\hline
\end{tabular}


WHC-SD-WM-ER-434, Revision 0

Table 8: Demonstration Test Glass Analyses (Wt\%)

\begin{tabular}{|c|c|c|c|c|c|c|}
\hline $\begin{array}{c}\text { Sample } \\
\text { No. }\end{array}$ & $\begin{array}{l}\text { Target } \\
\text { Values }\end{array}$ & W1G07-404C & W1G07-412C2 & H1G07-419C3 & H1G07-425C4 & W1G07-425U4 \\
\hline Date & & $12 / 07 / 94$ & $12 / 08 / 94$ & $12 / 08 / 94$ & $12 / 08 / 94$ & $12 / 08 / 94$ \\
\hline Time & . & $17: 00: 00$ & $01: 09: 00$ & $09: 00: 00$ & $15: 00: 00$ & $15: 00: 00$ \\
\hline Spg & & 2.58 & 2.57 & 2.60 & 2.58 & \\
\hline $\mathrm{SiO} 2$ & 42.90 & 37.4 & 37.5 & 35.5 & 35.2 & 39.8 \\
\hline $\mathrm{Na2O}$ & 18.82 & 19.7 & 18.2 & 20.8 & 21.0 & 20.3 \\
\hline Al203 & 18.22 & 19.4 & 18.4 & 17.8 & 18.7 & 19.1 \\
\hline $\mathrm{B} 203$ & 9.45 & 6.67 & 7.95 & 7.46 & 7.17 & 6.92 \\
\hline $\mathrm{CaO}$ & 4.65 & 4.32 & 4.34 & 3.92 & 3.99 & 4.06 \\
\hline $\mathrm{ZrO2}$ & 2.10 & 2.18 & 2.13 & 1.92 & 2.00 & 1.92 \\
\hline $\mathrm{K} 20$ & 1.44 & 0.97 & 0.97 & 1.07 & 1.06 & 1.01 \\
\hline Li20 & 0.83 & 0.84 & 0.81 & 0.73 & 0.81 & \\
\hline $\mathrm{BaO}$ & 0.00 & 1.05 & 1.29 & 2.53 & 1.55 & 1.68 \\
\hline $\mathrm{Fe} 2 \mathrm{O} 3$ & 0.00 & 0.71 & 0.62 & 0.52 & 0.77 & 0.75 \\
\hline P205 & 0.00 & 0.16 & 0.11 & 0.15 & 0.19 & 0.21 \\
\hline Mo03 & 0.00 & 0.14 & 0.13 & 0.16 & 0.16 & 0.17 \\
\hline SrO2 & 0.00 & 0.16 & 0.14 & 0.14 & 0.15 & 0.15 \\
\hline MgO & 0.00 & 0.084 & 0.073 & 0.063 & 0.080 & 0.12 \\
\hline TiO2 & 0.00 & 0.028 & 0.032 & 0.057 & 0.045 & 0.075 \\
\hline $\mathrm{Cr} 203$ & 0.00 & 0.037 & 0.036 & 0.046 & 0.058 & 0.057 \\
\hline $\operatorname{cs} 20$ & 0.00 & 0.028 & 0.032 & 0.034 & 0.031 & 0.034 \\
\hline$F-$ & 0.00 & 0.04 & 0.04 & 0.03 & 0.03 & 0.04 \\
\hline $\mathrm{MnO2}$ & 0.00 & 0.008 & 0.007 & 0.009 & 0.014 & 0.037 \\
\hline $\mathrm{NiO}$ & 0.00 & -0.004 & -0.004 & -0.004 & -0.004 & 0.002 \\
\hline 503 & 0.00 & 0.15 & 0.15 & 0.19 & 0.19 & 0.15 \\
\hline $\mathrm{Cl}-$ & 0.00 & 0.052 & 0.054 & 0.069 & 0.061 & 0.060 \\
\hline
\end{tabular}

The glass product did contain alumina crystals from the tuyere refractory. Such refractory loss in no way affected the product quality during the tests to date.

\subsubsection{Production Rate}

In the test facility, scoping and demonstration tests exhibited an average of 6.9 tonnes per day per torch during steady state operation. This production rate was based upon the use of a glass frit at power supply levels averaging 1.47 MWe. 


\subsection{FULL SCALE APPLICATION}

Westinghouse Science and Technology Center has provided their conceptual plan for a full scale application of the plasma melter concept. This plan is available in WHC-SD-WM-VI-015. In abstract, they have proposed the use of three to four melters, operating in cold-skull configuration.

\subsubsection{Facility Description}

As described and referred above, the WSTC concept for a $200 \mathrm{MT} /$ day plasma melter facility is that of three to four melters operating in cold skull configuration. Current Westinghouse Hanford Company interpretations of this concept yield core operations depicted in Figure 9, with streams defined in Table 10 .

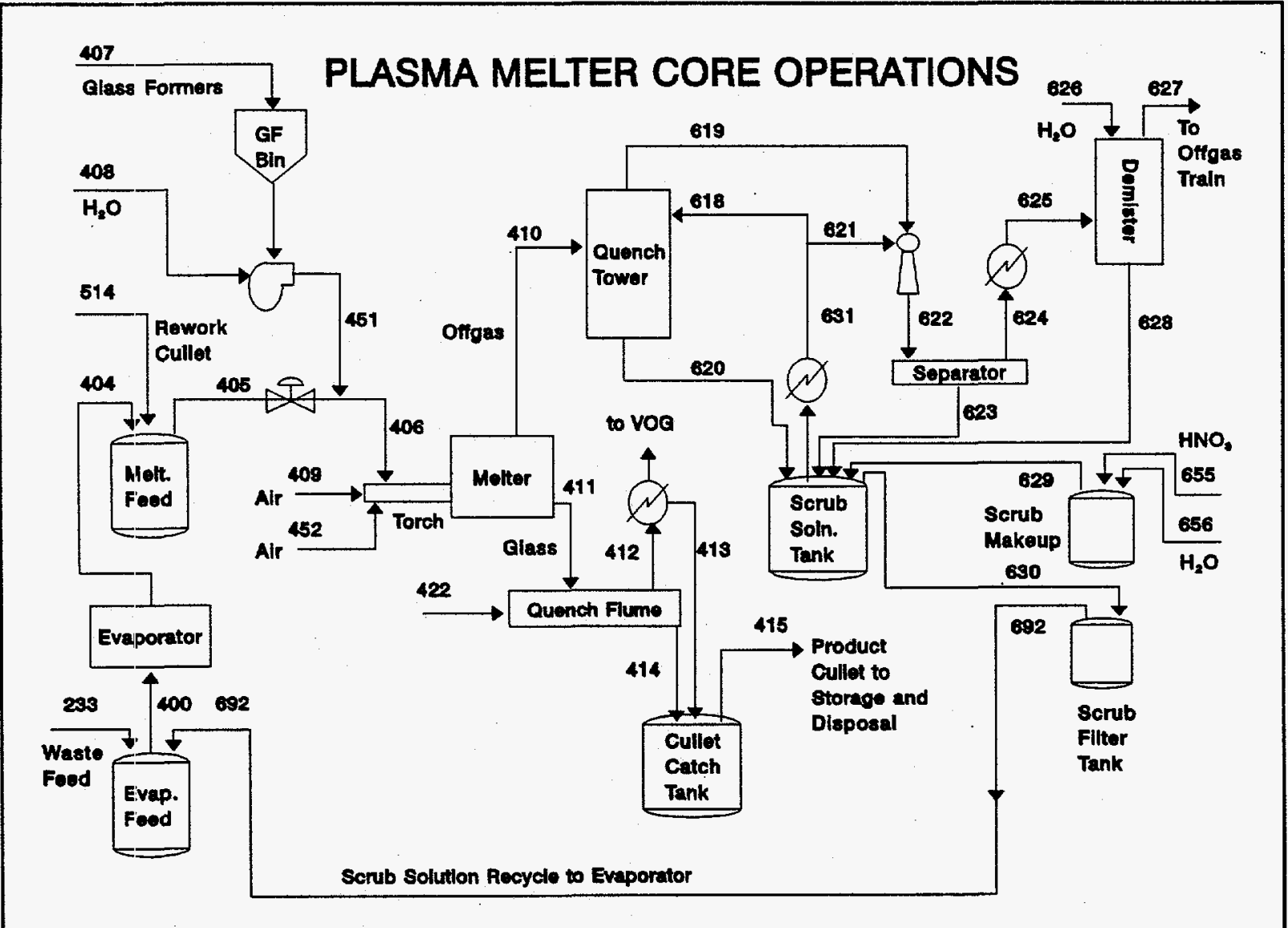

Figure 9: Plasma Melter Core Operations

Each melter, of about $3 \mathrm{~m}$ internal diameter, would be expected to be circumscribed by ten tuyeres mounted at an angle of approximately $30^{\circ}$ off normal. The melter would likely require a high-nickel cast inner shell with 
WHC-SD-WM-ER-434, Revision 0

Table 10: Plasma Melter Core Operations Stream Definitions

\begin{tabular}{|c|c|c|c|c|c|c|c|}
\hline 404 & Evaporator Product & 412 & $\begin{array}{l}\text { Quench Flume } \\
\text { Water Vapor }\end{array}$ & 618 & $\begin{array}{l}\text { Quench Liquor to } \\
\text { Quench Tower }\end{array}$ & 627 & Demister OHDS \\
\hline 405 & $\begin{array}{l}\text { Waste Slurry: } \\
514+404\end{array}$ & 413 & $\begin{array}{l}\text { Condensate Return } \\
\text { Quench Flume }\end{array}$ & 619 & $\begin{array}{l}\text { Quench Tower } \\
\text { OHDS }\end{array}$ & 628 & Demister BTMS \\
\hline 406 & $\begin{array}{l}\text { Tuyere Feed: } \\
405+451\end{array}$ & 414 & $\begin{array}{l}\text { Quench Flume } \\
\text { Product }\end{array}$ & 620 & $\begin{array}{l}\text { Quench Tower } \\
\text { BTMS }\end{array}$ & 629 & $\begin{array}{l}\mathrm{Aq} \mathrm{HNO}_{3} \text { scrubber } \\
\text { makeup }\end{array}$ \\
\hline 407 & $\begin{array}{l}\text { Mixed Glass } \\
\text { Formers }\end{array}$ & 415 & $\begin{array}{l}\text { Cullet Slurry } \\
\text { Product: } 413+414\end{array}$ & 621 & $\begin{array}{l}\text { Quench Liquor to } \\
\text { Venturi }\end{array}$ & 630 & $\begin{array}{l}\text { Quench Liquor to } \\
\text { Filter and Recycle }\end{array}$ \\
\hline 408 & $\begin{array}{l}\text { Giass former Slurry } \\
\mathrm{H}_{2} \mathrm{O}\end{array}$ & 422 & $\begin{array}{l}\text { Quench Supply to } \\
\text { Flume }\end{array}$ & 622 & $\begin{array}{l}\text { Venturi output to } \\
\text { separator }\end{array}$ & 631 & $\begin{array}{l}\text { Quench Liquor: } \\
618+621\end{array}$ \\
\hline 409 & Torch Air & 451 & $\begin{array}{l}\text { Glass Former Sturry: } \\
407+408\end{array}$ & 623 & $\begin{array}{l}\text { Separated solids and } \\
\text { liquids }\end{array}$ & 655 & Bulk $\mathrm{HNO}_{3}$ \\
\hline 410 & Melter Offgas & 452 & Shroud Air & 624 & $\begin{array}{l}\text { Separated liquids } \\
\text { and gases }\end{array}$ & 656 & Bulk $\mathrm{H}_{2} \mathrm{O}$ \\
\hline 411 & $\begin{array}{l}\text { Melter Glass } \\
\text { Product }\end{array}$ & 514 & $\begin{array}{l}\text { Crushed Slurried } \\
\text { Rework Cullet }\end{array}$ & 626 & $\begin{array}{l}\text { Demister wash } \\
\text { water }\end{array}$ & 692 & $\begin{array}{l}\text { Quench Liquor } \\
\text { Recycle to Evap. }\end{array}$ \\
\hline
\end{tabular}

water coolant flowing to at least four separate flow paths with redundant coolant water availability. Each tuyere, as a separable unit, would require cooling water in its jacket and a waste feed 7 ine. The plasma torch requires deionized water for electrode coolant and filtered working gas (instrument air). Each torch would be expected to operate at approximately 1.5 MWe.

Overall floor requirements would be approximately $15 \mathrm{~m}$ by $70 \mathrm{~m}$. Each melter would be expected to mass approximately 24 MT empty with an inventory of less than 0.7 tonne.

Although the torch currently in use at WSTC is relatively easily maintained, the application of an isolation valve across the tuyere (presumably a gate) for shine mitigation in radioactive operation has not been developed.

\subsubsection{Scale-Up Assessment and Contingencies}

Scale-up is not considered to be difficult for the plasma vitrification process. Indeed, the appropriate term is that of 'scale-down' inasmuch as the proposed full scale facility operates each torch to produce approximately $5 \mathrm{MT} /$ day of glass product while testing has proceed at a mean of $6.8 \mathrm{MT} /$ day. The only issues of scale are those of feed batchformer mixing and preparation, and the technical difficulties of handling a number of separate feed streams to individual tuyeres. As the issue of batch distribution remains for all applicable melter configurations, this is not considered to be a major constraint. 
WHC-SD-WM-ER-434, Revision 0

THIS PAGE INTENTIONALLY LEFT BLANK 


\subsection{REFERENCES}

Delegard, C. H., R. F. Creed, D. W. Hendrickson, D. F. McLaught in, 1994, Calcination/Dissolution Process Development 1994, WHC-SP-1093, Westinghouse Hanford Company, Richland, Washington, June 1994.

Hendrickson, D. W., 1995, Hanford Low-Level Vitrification Melter Testing Master List of Data Submittals, WHC-SD-WM-ML-001, Revision 0, Westinghouse Hanford Company, Richland, Washington, March 15, 1995.

WHC-SD-WM-VI-011, Test P7an for Evaluation of P7asma Melter Technology for Vitrification of High-Sodium Content Low-Level Radioactive Liquid Wastes, December 2, 1994.

WHC-SD-WM-VI-014, Evaluation of Plasma Melter Technology for Vitrification of High-Sodium Content Low-Leve] Radioactive Liquid Wastes -- Demonstration Test \#4 Preliminary Test Report, January 10, 1995.

WHC-SD-WM-VI-015, Technical Information Report: Plasma Melter Operation, Reliability, and Maintenance Analysis, March 14, 1995.

Wilson, C. N., 1994, Evaluation of Melter System Technologies for Vitrification of High Sodium Content Low Level Radioactive Liquid Wastes, WHC-SD-WM-RD-044, Revision 0, Westinghouse Hanford Company, Richland, Washington, March 16, 1994. 
WHC-SD-WM-ER-434, Revision 0

THIS PAGE INTENTIONALLY LEFT BLANK 
WHC-SD-WM-ER-434, Revision 0

\section{APPENDIX A - PHOTOGRAPHIC RECORDS}

Figure captions: Westinghouse Science and Technology Center Melter Testing Demonstration Testing December 7-8, 1994: $26 \mathrm{hr}$ run at $7.1 \mathrm{Mg} /$ day

Photograph records: Photograph negatives are stored in RIDS by number. Contact Hanford Site photographic services.

$95030460-3 \mathrm{CN}$

$95030460-8 \mathrm{CN}$

$95030460-6 \mathrm{CN}$

$95030460-4 C N$

$95030460-5 \mathrm{CN}$

$95030460-7 \mathrm{CN}$

$95030460-1 \mathrm{CN}$
Pan view of melter shaft with upper decking showing offgas ducting. Portholes view into crucible area of melter.

Roger Swensen (WSTC ME) inspecting setup of plasma torch. Foreground: power leads to end of torch assembly. Midground: utilities connections to utility flange including cooling water, deionized (DI) water for electrodes, torch air and shroud air.

Control Room setup for test bed. Operational control panels in commercial use much smaller than this test bed which is highly instrumented.

Product receivers - carbon steel mold boxes in sand beds within mine cars on tracks - run under the crucible. The tap is on the opposite side of the crucible.

Sample acquisition and logging and glass pouring. Facility liquid samples (feed simulant, feed slurry and scrubber liquor) are logged on the left while the background contains the mold box with glass product pouring at $-4.7 \mathrm{~kg} / \mathrm{min}$.

Glass product pouring from the tap into a mold box. Glass temperatures during the test ranged from $1200^{\circ} \mathrm{C}$ to $1370^{\circ} \mathrm{C}$. Each mold box contained approximately $500 \mathrm{~kg}$. With $7,700 \mathrm{~kg}$ produced. The tap is shrouded with an insulating board to retain heat and glass fluidity within the spout area.

Crucible upon melter unit disassembly. A vary small amount of material is in residence within the melter at any time with an average residence of less than 30 minutes in the crucible. Flow is controlled by temperature control of the viscosity of the glass to limit head over the weir at the tap. 


\section{WHC-SD-WM-ER-434, Revision 0}

95030460-2CN William Gass (WSTC Plant Engineer) and technician load out feed simulant from drums to heated, mixed fiberglass feed tank. Stirring device mounted mid-right. Tank feed system includes high volume recycle to maintain solids suspension. Settled solids in received waste simulant (evident on lip of drum) exceeded 15 wt\%. Background: Westinghouse Plasma Diamond Deposition Facility. 